\title{
PENGOLAHAN FILM RADIOGRAFI SECARA OTOMATIS MENGGUNAKAN AUTOMATIC X-RAY FILM PROCESSOR MODEL JP-33
}

\author{
Zoucella Andre Afani $^{1}$, Ni Nyoman Rupiasih ${ }^{1^{*}}$
}

\author{
${ }^{1}$ Jurusan Fisika, Fakultas Matematika dan Ilmu Pengetahuan Alam, \\ Universitas Udayana, Kampus Bukit Jimbaran, Badung, Bali Indonesia 80361. \\ "Email : rupiasih@unud.ac.id
}

\begin{abstract}
Abstrak
Telah dilakukan penelitian tentang proses pembentukan gambar pada film radiografi dan teknik pengolahannya secara otomatis. Penelitian dilakukan menggunakan pesawat sinar-X Toshiba E 7239, Fil AGFA Healtcare HV Septestraat 27B2640 Mortsel dan pengolah film otomatis“Automatic X-Ray Film Processor Model JP-33”. Dari hasil eksperimen diperoleh bahwa pada prinsipnya pencucian/pengolahan film otomatis sama dengan pengolahan film manual, kecuali tidak terdapat tahapan rinsing. Pengolahan film otomatis dapat menghemat waktu dan biaya, juga dapat mengurangi kemungkinan kesalahan Karena factor manusia.
\end{abstract}

Kata Kunci: Sinar-X, film radiografi, pengolahan film radiografi, automatic processing.

\begin{abstract}
A research on the process of forming an image on a radiographic film and processing techniques automatically has been done. The study was conducted using an X-ray plane Toshiba E 7239, Fil AGFA Healtcare HV Septestraat 27B2640 Mortsel and an automatic film processing "Automatic XRay Film Processor Model JP-33". The experimental results showed that the principle of automatic film processing is the same as the principle of film processing manually, except in automatic film processing there is no rinsing stage. Automatic film processing can save time and costs; also it can reduce the possibility of errors due to human factors.
\end{abstract}

Keywords: X-ray, radiographic film, radiographic film processing, automatic processing

\section{PENDAHULUAN}

Peranan bidang radiologi pada dunia kedokteran adalah cukup penting terutama di dalam menegakkan hasil pemeriksaan/ diagnosa. Pemeriksaan ini dapat memberikan informasi bagian tubuh yang mengalami kelainan, salah satu contohnya adalah patah atau retak tulang pada pergelangan tangan dan kaki akibat kecelakaan. Untuk memperoleh informasi atau gambaran internal tubuh yang akurat maka dibutuhkan kualitas radiograf atau foto Rontgen yang optimal.

Kualitas radiograf yang dihasilkan sangat dipengaruhi oleh beberapa faktor diantaranya tingkat kooperatif pasien, pemilihan faktor penyinaran dan proses pengolahan film yang tepat. Pengolahan film 
terdiri dari beberapa tahap yaitu pembangkitan (developer), pembilasan (rinsing), penetapan (fixing), pencucian (washing) dan pengeringan (drying). Proses pembangkitan dipengaruhi oleh suhu dan lamanya film berada dalam larutan pembangkit (Icky, 2011).

Terbentuknya gambar pada film radiografi diawali dengan tahap pembangkitan (developer) yaitu, perubahan butiranbutiran perak halida pada lapisan emulsi film setelah diradiasi dengan sinar- $X$ menjadi logam perak. Perubahan butiran-butiran perak halida tersebut tampak sebagai warna hitam pada film, atau dikatakan terjadi perubahan gambar/bayangan laten menjadi bayangan tampak. Tingkat kehitaman film sesuai dengan intensitas sinar- $X$ yang diterimanya, sedangkan yang tidak memperoleh penyinaran tetap bening. Selanjutnya tahap pembilasan dimana cairan pembilas membersihkan film dari larutan pembangkit supaya tidak terbawa ke proses selanjutnya.Tahap penetapan diperlukan untuk menetapkan dan membuat bayangan menjadi permanen dengan menghilangkan perak halida yang tidak terkena sinar-X. Tujuannya adalah untuk menghentikan aksi lanjutan yang dilakukan oleh cairan pembangkit yang terserap oleh emulsi film.Setelah proses penetapan akan terbentuk perak komplek dan garam. Bahan-bahan tersebut dihilangkan dengan cara mencuci menggunakan air mengalir.Tahap terakhir adalah pengeringan film.

Teknik pengolahan film dapat dikelompokkan menjadi dua yaitu otomatis dan manual. Pengolahan film manual adalah proses pencucian atau pemrosesan film yang dilakukan langsung oleh operator (petugas), tidak menggunakan mesin. Semua tahap pada proses pengolahan film dikerjakan secara manual oleh manusia, demikian halnya dengan pengaturan waktu dan suhunya sehingga kemungkinan terjadinya kesalahan cukup besar. Sedangkan pengolahan film otomatis adalah proses pencucian film yang dilakukan otomatis dengan menggunakan mesin. Suhu dan waktu pada setiap tahapnya telah diatur oleh sistem pada mesin, sehingga kesalahan yang mungkin terjadi dapat dikurangi(Icky, 2011). Pada kedua teknik tersebut, operator harus memiliki pengetahuan, keterampilan dan pengalaman yang cukup tentang pengaruh waktu dansuhupada proses pengolahan film, sehingga diperoleh kualitas radiograf yang optimal.

Pada makalah ini akan dilaporkan tentang proses pengolahan film radiografi secara otomatis dengan menggunakan automatic processing"Automatic X-Ray Film Processor Model JP-33". Juga ditampilkan beberapa data hasilp engolahan film radiografi menggunakan mesin tersebut.

\section{TINJAUAN PUSTAKA}

\subsection{Pesawat Sinar-X}

Pesawat sinar- $\mathrm{X}$ adalah pesawat yang menghasilkan gelombang elektromagnetik frekuensi tinggi yaitu 3-30 MHz sebut sinar$\mathrm{X}$, seperti tampak pada Gambar 2.1. Pesawat tersebut dilengkapi dengan sebuah sumber tegangan tinggi $20-200 \mathrm{kV}$, yang diperlukan untuk menghasilkan sinar-X pada tabung sinar-X. Penentuan besar dan waktu pengoperasiannya sangat bergantung pada besar dosis, kualitas radiograf dan kondisi tabung sinar-X. Semakin besar tegangan dan semakin lama waktu pengoperasiannya, maka dosis yang diterima pasien semakin besar, radiograf yang diperoleh semakin hitam, dan tabung sinar-X menjadi semakin panas. 
Padadunia kedokteran, sinar-X banyak digunakan untuk tujuan diagnosis (pemeriksaan) dan terapi (pengobatan). Pada diagnosis, sinar-X digunakan untuk melihat anatomi tubuh pasien seperti paru-paru, pergelangan tangan atau kaki dan kepala. Pada terapi, sinar-X banyak digunakan untuk membunuh sel-sel kanker. Sinar-X juga banyak digunakan di beberapa bidang diantaranya pada teknologi bahan, untuk analisa kualitatif dan kuantitatif suatu bahan dan kontrol kualitas (quality control). Pada teknik konstruksi, sinar-X digunakan untuk mendeteksi kebocoran, keretakan dan kualitas penyambungan. Serta untuk tujuan keamanan (safety) pemakaian sinar-X meliputi, pemeriksaan di airport (screening) dan pada tempat-tempat yang memerlukan pengamanan khusus.

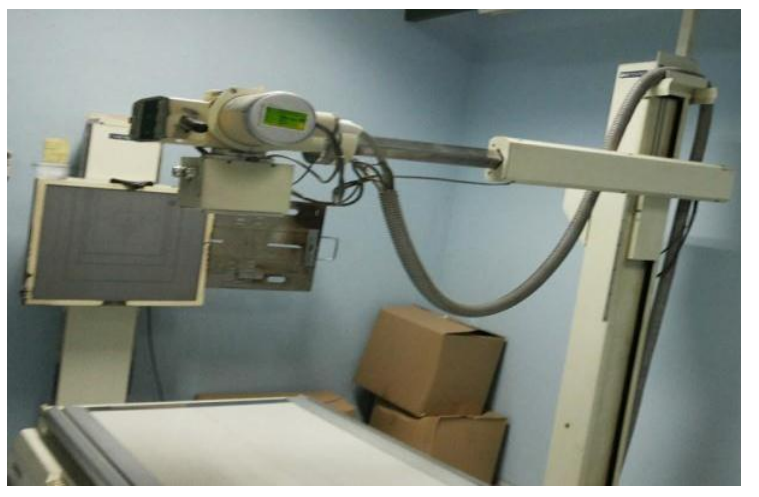

Gambar 2.1 Pesawat sinar-Xdi Klinik Quantum

\subsection{Film Rontgen}

Film Rontgen adalah film yang digunakan untuk pengambilan gambar bagian dalam tubuh, yang biasanya dilakukan di Unit Radiologi. Kualitas radiograf atau foto rontgen yang diperoleh sangat dipengaruhi oleh kondisi penyinaran serta proses pengolahan film. Untuk menjaga kualitas film sebelum digunakan maka perlu diperhatikan kondisi penyimpanan film. Syarat penyimpanan film yang baik meliputi suhu kira-kira $13{ }^{\circ} \mathrm{C}$, kelembaban udara maksimum $50 \%$, terlindung dari radiasi pengion (sinar-X) dan sinar gamma, jauh dari bahan kimia seperti developer atau fixer, serta tidak terjadi tekanan mekanik, baik diantara kotak-kotak film atau oleh bendabenda lainnya (Curry, 1990).

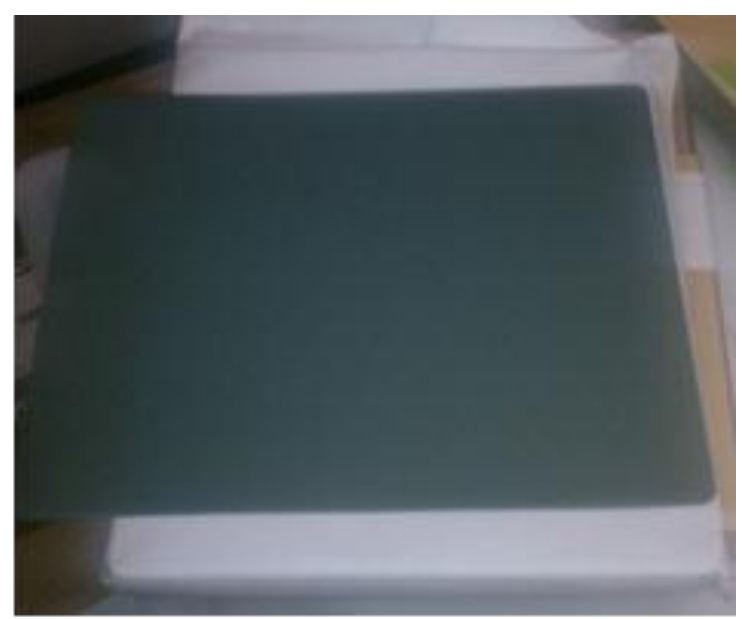

Gambar 2.2 Contoh film yang digunakan di Unit Radiologi

\section{METODE PENELITIAN}

Alat-alat yang digunakan pada penelitian ini yaitu pesawat sinar-X Toshiba E 7239 dengan nomor seri 20702, JPI Cassette Made In Japan, film AGFA HealthCare HV Septestraat $27 \quad$ B2640 Mortsel, Made In Belgia, dan automatic Xray film processor Model JP-33. Bahanbahan kimia yang digunakan yaitu developer replenisher dan fixer replenisher.

Setelah memperoleh hasil/ data foto Rontgen pasien, data diolah menggunakan komputer dan dicetak menggunakan mesin automatic processing. Dicetak juga menggunakan film dan kaset?

\section{HASIL DAN PEMBAHASAN}

Pada penelitian ini telah diperoleh data hasil pengamatan dari bulan Agustus sampai September 2016. diperoleh foto Rontgen untuk kasus patah tulang pada pergelangan tangan sebanyak 3 buah dan kaki sebanyak 8 buah. Salah satu foto Rontgen kasus patah tulang pada pergelangan tangan dan patah 
tulang pergelangan kaki diperlihatkan pada Gambar 4.1 dan 4.2.

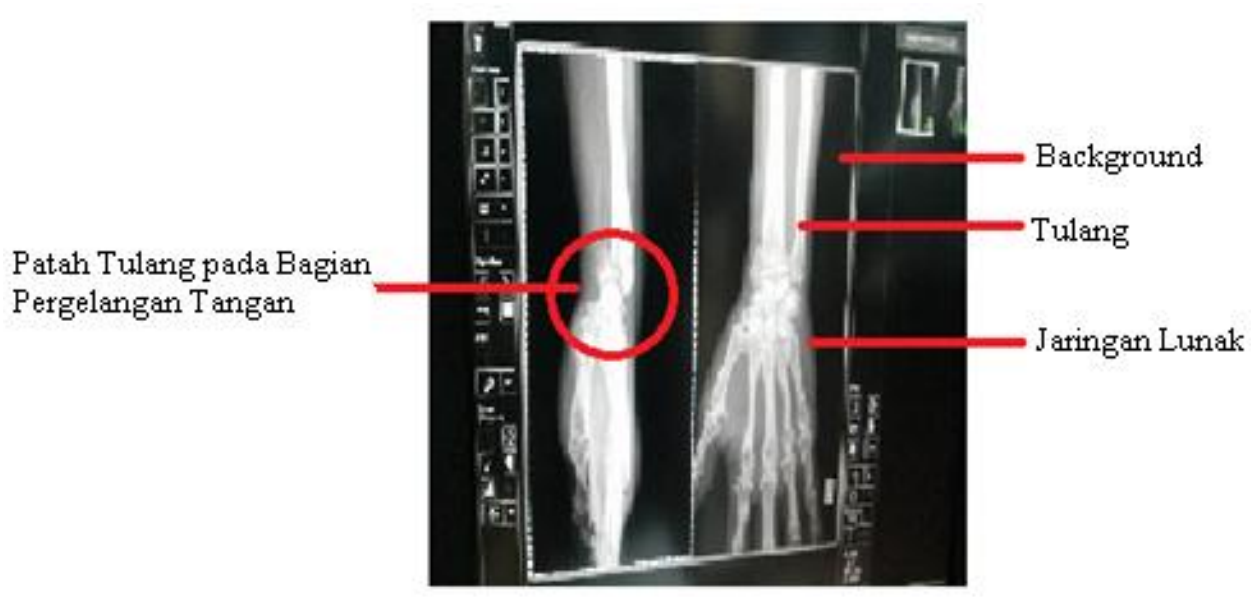

Gambar 4.1 Foto Rontgenpatah tulang pada pergelangan tangan

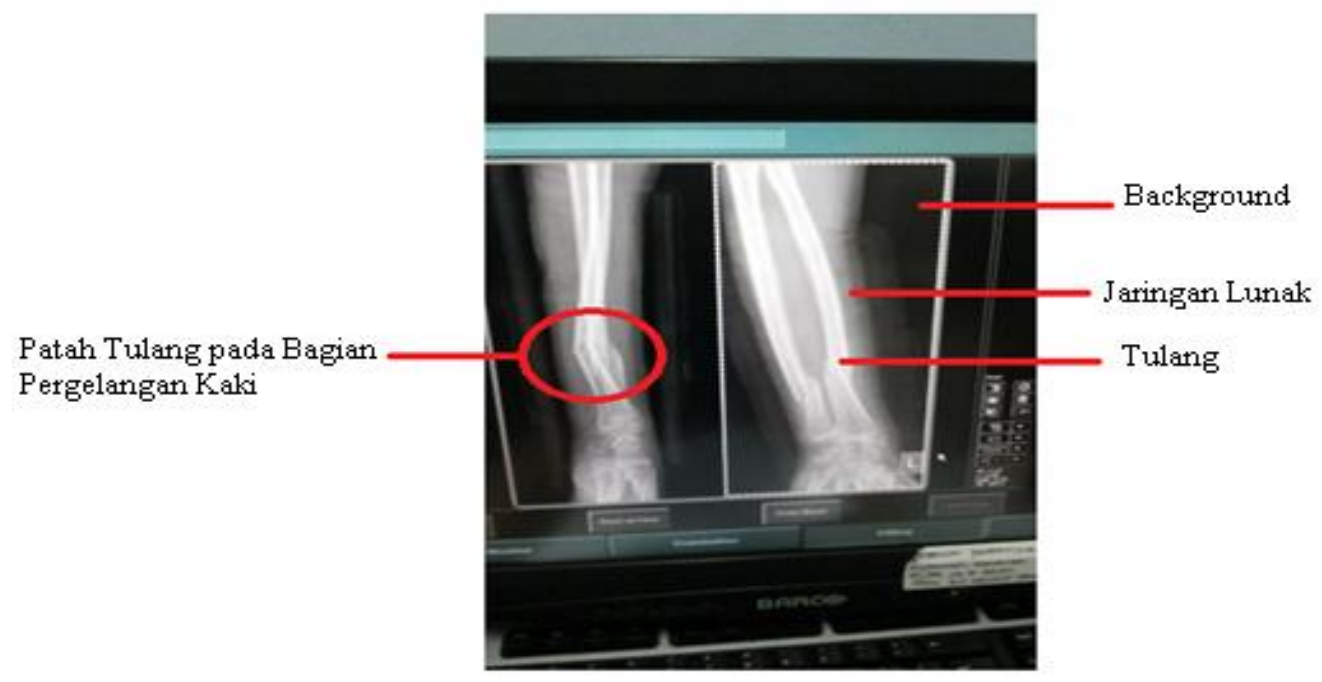

Gambar 4.2 Foto Rontgenpatah tulang pada pergelangan kaki

Pada prinsipnya pengolahan film otomatis dan pengolahan film manual adalah sama, hanya saja tidak terdapat tahapan rinsing. Tahapan-tahapan yang dimaksud adalah developing, fixing, washing dan drying. Untuk tahapan rinsing digunakan roller yang sudah terdapat di dalam mesin (Icky, 2011).

Ada beberapa alasan digunakannya mesinpengolah film otomatis diantaranya, pengolahan film bisa dilakukan dengan cepat. Totalwaktu dalamp engolahan film bervariasi yaitudari yang paling cepat 90 detik sampai yang paling lama 120 detik. Sedangkan padaproses manual diperlukan waktu antara 1 sampai 1,5 jam untuk mengolah sebuah film sampai benar-benar kering. Pengolahan dapat dilakukan lebih praktis dan bersih. Semua proses dilakukan di dalam mesin sehingga tidak ada air yang jatuh di kamar gelap dan tidak diperlukan hanger untuk menjepit film karena mesin mempunyai roller yang berfungsi sebagai penjepit film selama proses berjalan. Pengolahan film sudah ada waktu yang 
standar, ukuran kamar gelap relatif kecil, serta total biaya lebih murah (Curry, 1990).

Gambar 4.1 dan 4.2 masing-masing memperlihatkan foto Rontgen dari pasien patah tulang pada pergelangan tangan dan kaki. Tampak bahwa bagian film yang berwarna paling gelap atau hitam adalah "background" yaitu bagian film yang terekpos atau menerima radiasi sinar- $\mathrm{X}$ paling banyak, karena tidak ada bagian radiasi yang terserap oleh obyek. Bagian film yang berwarna lebih terang adalah bagian jaringan lunak. Pada bagian ini, sebagian radiasi sinar- $\mathrm{X}$ diserap oleh bagian jaringan lunak dari obyek seperti daging dan lemak. Dan bagian film yang berwarna putih yaitu bagian yang berbentuk kerangka tangan dan kaki adalah bagian film yang terekpos radiasi sinar- $X$ paling sedikit dibandingkan dengan dua bagian yang sudah dijelaskan sebelumnya. Pada bagian ini, sebagian besar radiasi diserap oleh tulang tangan dan kaki. Tulang adalah merupakan bagian tubuh yang sangat padat dan keras, sehingga dapat menyerap sebagian besar radiasi yang melewatinya. Obyek atau bahan yang lebih rapat akan menyerap radiasi lebih banyak dibandingkan dengan bahan yang lebih renggang atau lunak. Hal ini akan mempengaruhi jumlah radiasi yang dapat melewati bahan dan mengenai film sehingga terbentuklah gambar obyek yang merupakan rangkaian dari densitas atau derajat masing bagian film tersebut tampaklah gambaran bagian internal tubuh dari pasien. Dengan membandingkan foto Rontgen dari orang sehat dengan foto Rontgen dari pasien maka dapat dianalisa bagian-bagian tubuh pasien yang sakit atau bermasalah, seperti tampak pada Gambar 4.1 dan 4.2.

\section{KESIMPULAN}

Pada penelitian ini dapat disimpulkan bahwa pada prinsipnya pengolahan/ pencucian film otomatis sama dengan pengolahan film manual, kecuali tidak terdapatnya tahapan rinsing. Pengolahan film secara otomatis dapat menghemat waktu, biaya dan mengurangi kemungkinan kesalahan karena faktor manusia.

\section{DAFTAR PUSTAKA}

Curry. 1990. Densitas dan Tingkat Kehitaman Film. Jakarta: Universitas Indonesia.

Icky. 2011. Tahapan Pengolahan Film Secara Utuh. Jakarta: Universitas Indonesia.

Icky. 2011. Film Rontgen. Jakarta: Universitas Indonesia.

2014. www.computersrecyclingcompany.com/ xrays.htm. Dikases pada tanggal 8 Februari 2017. kehitaman film. Perbedaan dari tingkat atau derajat kehitaman (densitas) pada masing- 